\title{
VERSUS COLÔMBIA - A TRÍADE PAZ, DIREITOS HUMANOS E DEMOCRACIA ANALISADA A PARTIR DE JULGADOS DO SISTEMA INTERAMERICANO DE DIREITOS HUMANOS
}

\author{
VERSUS COLOMBIA - PEACE, HUMAN RIGHTS AND DEMOCRACY \\ TRIAD ANALYZED FROM INTER-AMERICAN HUMAN RIGHTS SYSTEM \\ CASES
}

Ananda Hadah Rodrigues Puchta

Universidade Federal do Paraná - UFPR - (Curitiba, PR, Brasil)

Melina Girardi Fachin

Universidade Federal do Paraná - UFPR - (Curitiba, PR, Brasil)

Giulia Fontana Bolzani

Universidade Federal do Paraná - UFPR - (Curitiba, PR, Brasil)

Recebimento: 22 fev. 2017

Aceitação: 7 nov. 2017

\begin{abstract}
Como citar este artigo / How to cite this article (informe a data atual de acesso / inform the current date of access):
PUCHTA, Ananda Hadah Rodrigues; FACHIN, Melina Girardi; BOLZANI, Giulia Fontana. Versus Colômbia - A tríade paz, direitos humanos e democracia analisada a partir de julgados do Sistema Interamericano de Direitos Humanos. Revista da Faculdade de Direito UFPR, Curitiba, PR, Brasil, v. 62, n. 3, p. 31-59, set./dez. 2017. ISSN $2236-7284$. Disponível em: <http://revistas.ufpr.br/direito/article/view/50862>. Acesso em: 21 dez. $2017 . \quad$ DOI: http://dx.doi.org/10.5380/rfdufpr.v62i3.50862.
\end{abstract}

\section{RESUMO}

O objetivo do artigo é analisar a contribuição do Sistema Interamericano de Direitos Humanos, em especial da sua jurisdição contenciosa, para o fortalecimento do processo democrático, da rule of law e do estabelecimento da paz no território colombiano. Para tanto, parte da premissa de um direito aberto, plural e multinível de impactos recíprocos entre direito interno e internacional em frutífero diálogo. Analisa-se, a partir de uma breve explanação do funcionamento do aparato regional, a jurisprudência da Corte - qualitativamente selecionada - a fim de demonstrar como a sua atuação jurisdicional compeliu o Estado colombiano a tomar medidas de fortalecimento de direitos humanos no país, o que contribuiu decisivamente para o processo de paz. Sendo assim, busca-se apresentar a influência positiva do Sistema Interamericano de Direitos Humanos, mediante a atuação contenciosa da Corte IDH, na construção de uma cultura de paz, direitos humanos e democracia, eixos fundamentais para o fortalecimento institucional do Estado Democrático de Direito.

\section{PALAVRAS-CHAVE}

Direitos Humanos. Democracia. Paz. Colômbia.

\begin{abstract}
The purpose of this article is to analyze the contribution of the Inter-American Human Rights system, especially its contentious jurisdiction, to strengthening the democratic process, the rule of law and the establishment of peace in Colombia. To do so, it starts from the premise of an open, plural and multilevel right of reciprocal impacts between domestic and international law in meaningful dialogue.
\end{abstract}


From a brief explanation of the operation of the regional apparatus, the jurisprudence of the Court qualitatively selected - is examined in order to demonstrate how its jurisdictional action has compelled the Colombian State to take measures to strengthen human rights in the country, contributing decisively to the peace process. Thus, it seeks to present the positive influence of the Inter-American Human Rights system, through the contentious actions of the Inter-American Court of Human Rights, in the construction of a culture of peace, human rights and democracy, fundamental axes for institutional strengthening of the Democratic Rule of Law in Colombia.

\section{KEYWORDS}

Human Rights. Democracy. Peace. Colombia.

\section{INTRODUÇÃO}

É manifesto que a Colômbia foi, por muitos anos, cenário de um dos conflitos armados não internacional mais longos, e de graves e sistemáticas violações de direitos humanos. É justamente nesse contexto complexo, intenso e violento que a influência de normas internacionais de direitos humanos produziu significativa diferença.

Quase trezentos mil mortos - na sua maioria civis -, milhares de desaparecidos e mais de seis milhões de deslocados internos são o saldo das décadas de conflito entre o Estado colombiano e as Forças Armadas Revolucionárias da Colômbia (FARC) ${ }^{1}$. O acordo de paz integral e definitivo foi firmado em solo cubano, em agosto de 2016.

Um conflito complexo motivado por causas sociais, políticas e econômicas diversas teve também um desfecho heterodoxo. O tripé que sustentou o longo conflito repousa na "tendência a usar a violência no poder e na política, [n]a falta de resolução sobre a questão da propriedade da terra no campo e [n]a falta de garantias para a pluralidade e exercício da política”, destaca Álvaro Villarraga Sarmiento (CENTRO NACIONAL DE MEMORIA HISTÓRICA, 2014, Prefácio), do Centro Nacional de Memória Histórica².

Se for certo que a assinatura do acordo de paz não põe fim ao conflito ipso facto, o caminho até sua assinatura foi um processo emaranhado no qual múltiplos fatores influenciaram. Para a presente reflexão é a influência do direito internacional dos direitos humanos que interessa destacar.

O presente artigo tem como hipótese a contribuição do Sistema Interamericano de Direitos Humanos, mormente na figura de sua Corte, para o fortalecimento do processo democrático, da rule

\footnotetext{
${ }^{1}$ As Forças Armadas Revolucionárias da Colômbia compreendem um grupo armado colombiano, criado em 1964. FARC são as iniciais do movimento, as quais serão utilizadas no presente artigo como abreviatura.

2 Tradução livre do contido no prefácio da obra CENTRO NACIONAL DE MEMORIA HISTÓRICA. Yo aporto a la verdad, acuerdos de contribución a la verdad y la memoria histórica: mecanismo no judicial de contribución a la verdad, la memoria histórica y la reparación, Ley 1424/2010 / Centro Nacional de Memoria Histórica - Dirección de acuerdos de la verdad. Editor Álvaro Villarraga Sarmiento. Bogotá: Centro Nacional de Memoria Histórica, 2014.
} 
of law e da paz no território colombiano. É certo que tal não ocorreu tout court e dependeu da modificação de muitas estruturas internas, já que o direito internacional apenas pode tocar aqueles a ele abertos ${ }^{3}$.

Com essa hipótese em mente analisar-se-á, por meio de levantamento qualitativo da jurisprudência da Corte interamericana em relação ao Estado colombiano, esta inter-relação entre o sistema internacional de direitos humanos e o sistema interno de fortalecimento do Estado de Direito e da cultura da paz. Antes, todavia, algumas notas sobre o Sistema Interamericano de Direitos Humanos são necessárias, apenas para compreensão de funcionamento e estrutura.

Como advertência metodológica preliminar consta a postura dialógica e aberta que o direito constitucional plural, múltiplo e poroso do século XXI nos exige. Impossível seria tratar das imbricações do processo de internacionalização dos direitos humanos com a experiência de consolidação democrática e da paz na Colômbia sem que o intercâmbio entre os sistemas fosse colocado como premissa.

O sucesso dos sistemas regionais de direitos humanos, entretanto, depende, em larga escala, do grau de comprometimento dos Estados que os compõem. Nas palavras de Cançado Trindade (2003, p. 91), “o futuro do sistema internacional de proteção dos direitos humanos está condicionado aos mecanismos nacionais de implementação”. O diálogo deve, portanto, densificar-se entre as esferas locais e regionais no sentido de mútuo reforço, pois - nas expressões de Jack Donnelly (2003, p. 141) - "good national human rights records" implicam "strong international procedure".

Os avanços das searas regionais, tanto em termos de normatividade quanto no que concerne à implementação prática, passam pelo compromisso dos Estados e sua vontade política de funcionar os sistemas. É justamente nesse influxo que a força e potencialidade da justiça internacional devem, ao fim e ao cabo, traduzir-se na proteção dos direitos humanos no âmbito interno dos Estados, no local ocupado pelas vítimas. É desta indissociabilidade que se parte - a partir das lentes do sistema interamericano - para ler a experiência colombiana.

A pesquisa desenvolveu-se, assim, com base na doutrina especializada na matéria e na análise dos casos julgados contra o Estado colombiano na Corte interamericana de Direitos Humanos. Em que pese a importância da Comissão Interamericana de Direitos Humanos, conforme abaixo se destacará, o foco na Corte foi utilizado por ser ela o órgão jurisdicional responsável pela última

\footnotetext{
${ }^{3}$ Desse modo, para que a ratificação dos tratados exerça efeitos benéficos no desempenho dos Estados, é preciso que existam condições para que grupos domésticos, partidos, indivíduos e organizações da sociedade civil possam persuadir, convencer e pressionar os governos a traduzir suas promessas de melhores práticas em realidade (BERNARDI, 2013, p. 145).
} 
palavra no sistema - ainda que extremamente precária e cambiante, haja vista, de um lado, a doutrina da margem da apreciação (GREER, 2000, p. 5) ${ }^{4}$ e, de outro, da compreensão dos instrumentos internacionais como living instruments ${ }^{5}$.

É certo que o processo interamericano de fortalecimento dos direitos humanos impactou na Colômbia de modo dúplice: de um lado com a abertura de sua sociedade civil para socorrer-se do sistema quando da falência estatal em dar respostas satisfatórias às massivas violações de direitos humanos ocorridas, e, de outro, como resultado desse recurso ao sistema, com as sentenças condenatórias que exigiram uma mudança de postura do Estado, que paulatinamente contribuíram com o fortalecimento da democracia e construção do processo de paz. É justamente a análise desse conjunto decisório que se pretende aqui enfocar.

\section{ADVERTÊNCIA METODOLÓGICA SUBSTANCIAL}

A advertência metodológica aqui exposta clama para a nova percepção do fenômeno jurídico que deflui da centralidade dos direitos humanos e do mantra da prevenção ao sofrimento humano espraiado em todo o globo. É método na medida em que muda o ângulo de visão do direito interno, o direito internacional e o direito público no geral. Ao mesmo tempo é substância, pois esta alteração ótica denota uma mudança na percepção dos conteúdos formativos desses campos. Esta renovada postura formal de resultados substanciais é fundamental para a presente análise.

A concepção contemporânea da proteção dos direitos humanos inaugurou uma nova esfera da responsabilidade dos Estados na implementação desses direitos, que deixaram de ser tema exclusivo da soberania constitucional e estatal. Isso impactou o modo de pensar e conceber não só os direitos humanos, mas também o direito internacional, o direito constitucional e suas fronteiras recíprocas. Aproximam-se, assim, as noções de direitos interno e direito internacional, sobretudo em matéria de direitos humanos.

Todavia, ainda é certo que a responsabilidade primária na realização dos direitos humanos, de modo geral, recai sobre os Estados, que em abstrato possuem maiores condições de dar uma resposta satisfatória às vítimas de violações de direitos humanos. Eis a razão pela qual o direito internacional dos direitos humanos opera por meio do código da subsidiariedade (OLIVEIRA, 2007,

\footnotetext{
${ }^{4}$ Doutrina europeia que "Broadly speaking it refers to the room for man oeuvre the Strasbourg institutions are prepared to accord national authorities in fulfilling their obligations under the European Convention on Human Rights” (GREER, 2000, p. 5).

${ }^{5}$ A interpretação evolutiva tem o intuito de contextualizar os elementos de proteção previstos no pacto, mantendo-os vivos e conectados à realidade e às demandas circundantes. Com base nesta principiologia dinâmica e evolutiva é que a Corte Europeia de Direitos Humanos tem resgatado a proteção dos direitos sociais, mesmo que de modo indireto.
} 
p. 147-148) ${ }^{6}$ : apenas quando o Estado não possui estruturas internas suficientes ou não deu conta de resolver satisfatória, adequada e tempestivamente a demanda que lhe foi exposta, é que o aparato internacional entra em cena.

Esse novo cenário demanda um alargamento da visão publicista tradicional, segundo a qual o Estado guarda responsabilidades apenas diante dos direitos humanos de seus cidadãos (TRINDADE, 1997, p. 175) ${ }^{7}$. Ainda que ao Estado caiba a responsabilidade primária, destaca-se a importância da interface e do diálogo dos diferentes planos protetivos para a realização dos direitos humanos - o que demanda a relação entre os constitucionalismos locais e o direito internacional dos direitos humanos.

Emerge, dessa forma, uma nova forma de direito público - lastreado na coexistência de diversas ordens paralelas e harmônicas entre si - que deve dialogar em torno do princípio pro persona e que se vê "pautada pela força expansiva do princípio da dignidade humana e dos direitos humanos, conferindo prevalência ao human centered approach” (PIOVESAN, 2012, p. 72).

O direito interno e o direito internacional acabam por se impactar mutuamente e dessa catarse emerge uma nova ordem internacional e um novo direito público internacional e estatal. Na relação entre essas duas camadas ressignificam-se as estruturas internas e internacionais de proteção, de acordo com Flávia Piovesan:

[...] a crescente abertura do Direito - agora "impuro" -, marcado pelo diálogo do ângulo interno com o ângulo externo (há a permeabilidade do Direito mediante o diálogo entre jurisdições; empréstimos constitucionais; e a interdisciplinaridade, a fomentar o diálogo do Direito com outros saberes e diversos atores sociais, ressignificando, assim, a experiência jurídica). (PIOVESAN, 2012, p. 72).

É nesse clima de diálogo e de somatório de forças que a presente reflexão se lastreia, tomando como ponto de partida a imprescindível vinculação que os ângulos internos (aqui direito

\footnotetext{
6 "A subsidiariedade é princípio geral do Direito Internacional Público no que concerne à solução plurilateral de controvérsias em nível internacional. Significa que tribunais internacionais só poderão ser invocados após o exaurimento, sem sucesso, dos mecanismos internos para a solução do problema” (OLIVEIRA, 2007, p. 147).

${ }^{7}$ As iniciativas no plano internacional não podem se dissociar da adoção e do aperfeiçoamento das medidas nacionais de implementação, porquanto destas últimas - estamos convencidos - depende em grande parte a evolução da própria proteção internacional dos direitos humanos. A responsabilidade primária pela observância dos direitos humanos recai nos Estados, e os próprios tratados de direitos humanos atribuem importantes funções de proteção aos órgãos dos Estados. Ao ratificarem tais tratados, os Estados Partes contraem a obrigação geral de adequar seu ordenamento jurídico interno à normativa internacional de proteção, a par das obrigações específicas relativas a cada um dos direitos protegidos. No presente domínio de proteção, o direito internacional e o direito interno se mostram, assim, em constante interação. É a própria proteção internacional que requer medidas nacionais de implementação dos tratados de direitos humanos, assim como o fortalecimento das instituições nacionais vinculadas à vigência plena dos direitos humanos e do Estado de Direito. De tudo isto se pode depreender a premência da consolidação de obrigações erga omnes de proteção, consoante uma concepção necessariamente integral dos direitos humanos (TRINDADE, 1997, p. 175).
} 
colombiano) e externo (sistema interamericano) possuem, articulando-se em prol da consolidação do constitucionalismo democrático e da expansão das liberdades humanas.

\section{BREVES NOTAS SOBRE O SISTEMA INTERAMERICANO}

O Sistema Interamericano nasce peculiar, pois surge em um momento bastante paradoxal da região. O marco inicial é o Pacto de São José da Costa Rica, que entrou em vigor em 1978; neste momento ao menos metade dos países signatários não possuíam experiências democráticas no âmbito interno. Além disso, a lógica autoritária imperante valia-se da instabilidade política como pretexto para os conflitos internos e o uso truculento da força. É nesse contexto que o Sistema emerge, tendo contribuído de maneira substancial para a implementação do Estado Democrático de Direito na região.

O texto e o contexto - como ressalta Joaquín Herrera Flores (2009, p. 32) - são elementos nodais na compreensão do aparato regional interamericano, já que, em que pese ter nascido a exemplo do modelo europeu de proteção dos direitos humanos, o sistema regional vem firmando sua identidade própria, em especial tendo em vista as vicissitudes políticas que o permeia. Viviana Kristicevic anota que:

[...] em particular, a Comissão Interamericana e a Corte dos Direitos Humanos, os dois órgãos que fiscalizam a implementação dos instrumentos dos direitos humanos nas Américas, desenvolveram seus poderes e jurisprudência, a fim de evitar ou reformar as brutais e massivas violações de direitos humanos recorrentes na região (WILT; KRISTICEVIC, 2004, p. 371).

Inevitável é a comparação entre os sistemas, já que o europeu, como pioneiro, serviu de molde. Deve-se, contudo, levar em conta as grandes diferenças, inclusive orçamentárias, que os apartam. Importa sempre advertir que o sistema interamericano é de existência recente e que, em que pesem suas grandes conquistas, o aprimoramento faz-se imperativo também no sistema europeu com os enormes desafios atuais. Assim, mais que comparar impende aproximar e dialogar, como exposto no tópico acima.

Além da Corte Interamericana de Direitos Humanos, há, portanto, uma estrutura comissional. A Comissão Interamericana de Direitos Humanos tem como fito primordial promover a proteção dos direitos humanos nas Américas. Para a persecução de seu objetivo, três são as principais funções das Comissão: o processamento de reclamações individuais, a confecção de relatórios sobre a situação dos direitos humanos nos Estados membros, e proposição de medidas de fortalecimento dos direitos humanos na região. 
A Comissão é um dos órgãos mais importantes da região na promoção e proteção dos direitos humanos, tendo competência compulsória a todos os Estados integrantes da Organização dos Estados Americanos. Possui, ainda, uma atuação mais ampla do que a Corte, tendo em vista que sua base não convencional - resolução da Comissão de Direitos Humanos da OEA em 1959 - estende seu mandato para países não signatários da Convenção, como Estados Unidos e Canadá. Esclarece Antônio Cançado Trindade:

Criado (em 1959) por resolução (em vez de tratado), a Comissão Interamericana de Direitos Humanos limitava-se originalmente ao mandato da promoção dos direitos humanos e gozava de uma posição sui generis no Sistema Interamericano. Tão logo, esforçou-se para ampliar suas próprias competências, como um órgão de investigações in loco de situações de direitos humanos e de exame de comunicações que alegassem violações de direitos humanos. Suas atribuições e poderes ampliados compreendiam também um sistema de relatórios (de tipos distintos, tais como relatórios de sessões, relatórios anuais e relatórios de países específicos). Em 1967, com o Protocolo de Reforma da Carta da OEA (o qual entra em vigor em 1970) a Comissão foi finalmente estabelecida como um dos principais órgãos da OEA e, portanto, dotada de base convencional. Desde então, tem mantido sua dualidade de funções, vis-a-vis Estados parte da Convenção Americana, bem como Estados não signatários da Convenção (a estes últimos, aplica-se a Carta da OEA e a Declaração Americana de 1948). (TRINDADE, 2005, p. 53) ${ }^{8}$.

A Comissão, formada por sete experts, possui jurisdição acessível a todos os indivíduos e organismos não governamentais dos países membros. De acordo com o artigo 44 da Convenção Interamericana, qualquer pessoa, grupo de pessoas, ou entidade não governamental, tem legitimidade para apresentar uma petição à análise da Comissão. Tendo em vista a pusilanimidade dos Estados e Direito na região, e as frequentes ameaças a defensores de direitos humanos, a legitimidade aberta é bastante respeitável, já que muitas vítimas podem sofrer retaliações pela atuação internacional.

A Comissão é o principal organismo de acionamento da Corte Interamericana de Direitos Humanos, uma vez que apenas a Comissão Interamericana ou os Estados partes podem submeter uma lide à Corte. Essa, por sua vez, foi estruturada pela Convenção Americana dos Direitos Humanos, Pacto de São José da Costa Rica, como um engenho de salvaguarda dos direitos fundamentais no continente americano.

\footnotetext{
${ }^{8}$ Tradução livre do trecho: “Created (in 1959) by a resolution (rather than a treaty), the Inter-American Commission on Human Rights had originally a mandate limited to the promotion of human rights and enjoyed a sui generis position within the inter-American system. Soon it endeavored to enlarge its own competence, as an organ of in loco investigation of situations of human rights and of examination of communications of alleged violations of human rights. Its enlarged attributions and powers were also to comprise the reporting system (reports of distinct kinds, such as session and annual reports, and reports on specific countries). With the 1967 Protocol of Reform of the OAS Charter (which entered into force in 1970) the Commission was at last established as one of the main organs of the OAS and thus endowed with a conventional basis. Ever since it has had a duality of functions, namely, vis-a-vis States Parties to the American Convention as well as States not Parties to the Convention (as to these latter, on the basis of OAS Charter and 1948 American Declaration).” (TRINDADE, 2005, p. 53).
} 
A Corte é o órgão jurisdicional do sistema, composto por sete juízes eleitos a título pessoal pela Assembleia Geral da Organização dos Estados Americanos. É, nos termos de seu regulamento, instituição judiciária autônoma cujo objetivo é a aplicação e a interpretação da Convenção Americana sobre Direitos Humanos que lhe dá mandato.

Conta com competência dúplice: contenciosa (WILT; KRISTICEVIC, 2004, p. 378) e consultiva; esta última muito mais desenvolvida que no velho continente, o que demonstra a peculiaridade dos sistemas regionais. Acerca das atividades da Corte, explana Cançado Trindade:

Para o exercício da jurisdição contenciosa da Corte é necessária a ratificação da Convenção
Americana pelos Estados parte. Por sua vez, a jurisdição consultiva é particularmente ampla,
já que todos os Estados membros da OEA e todos os órgãos mencionados no capítulo X da
Carta da OEA podem solicitar pareceres à Corte sobre temas distintos (por exemplo,
interpretação da Convenção Americana ou de outros tratados relativos à proteção dos direitos
humanos nos Estados Americanos com a Convenção Americana ou outros tratados de
direitos humanos). A Corte também vem desenvolvendo, nos últimos anos, uma prática
notável sobre medidas provisórias ou preventivas de proteção. (TRINDADE, 2005, p. 53) ${ }^{9}$.

A competência litigiosa da Corte está, salvo exceções pontuais, na interpretação e aplicação da Convenção Americana de Direitos Humanos a que lhe seja submetida apreciação, em relação aos deveres dos Estados signatários que tenham expressa e apartadamente reconhecido esta competência, sendo necessário que se tenham esgotados os procedimentos previstos nesta Convenção. Representa, em realidade, o alargamento das atividades de peticionamento individual que se desenrola perante a comissão. No âmbito contencioso o Leading Case foi o Velásquez Rodrigues vs. Honduras, de 1989, que versa sobre desaparecimentos forçados.

Há, na atualidade, cinco grandes linhas jurisprudenciais destacadas por Flávia Piovesan (2004, p. 116-118). A primeira lida com as violações cometidas pelos próprios Estados diretamente como agentes da barbárie; a segunda foca na justiça de transição, cujo caso referência é Barrios Altos vs. Peru, que pioneiramente determinou que as leis de autoanistia são um ilícito internacional; a terceira destaca a contribuição à consolidação dos Estados de Direito, cujo julgado emblemático é aquele da Corte Constitucional vs. Peru - no qual os juízes constitucionais foram destituídos do cargo por contrariar os interesses executivos do governo Fujimori; a quarta trata de violações a direitos de grupos vulneráveis, nos quais se inserem os casos indígenas que recheiam a farta jurisprudência da

\footnotetext{
${ }^{9}$ Tradução livre do trecho: “For the exercise of the Court’s contentious jurisdiction, a declaration of acceptance is required from States Parties to the American Convention. In its turn, the advisory jurisdiction is particularly wide, given that all OAS member States and all organs mentioned in the chapter X of the OAS Charter can request advisory opinions from the Court on distinct topics (e.g., interpretation of the American Convention or of other treaties relating to the protection of human rights in the American States with the American Convention or other human rights treaties). The Court has also been developing, in recent years, a remarkable practice on provisional or interim measures of protection.” (TRINDADE, 2005, p. 53).
} 
corte sobre o tema - com evidência ao pioneiro caso da comunidade Awas Tingni vs. Nicarágua, em que a Corte reconheceu o direito à propriedade coletiva da terra. Por fim, a quinta e tímida linha é voltada à litigância indireta dos direitos sociais, pelas possibilidades do direito de petição no protocolo de San Salvador, destacando-se neste viés o caso dos Cinco Pensionistas vs. Peru.

O sistema repousa essencialmente sobre vasto rol de direitos civis e políticos (artigos $3 .^{\circ} \mathrm{a}$ 25 da Convenção); a Convenção Americana contém cláusula genérica de previsão de direitos sociais que entoa a progressividade da respectiva implementação, vinculando-os aos recursos disponíveis dos Estados (artigo 26). A fim de complementar a insuficiente proteção dos direitos sociais nas Américas, apenas em 1988 foi aprovado o Protocolo de San Salvador, que enuncia direitos ao bemestar social e traz consigo um dilatado inventário de direitos econômicos, sociais e culturais que abrange garantias trabalhistas, direitos sindicais e garantias previdenciárias, inclusive o direito à saúde, à educação e à cultura, entre diversos outros, à exceção dos direitos ambientais. Todavia, à exceção do direito à educação e do direito à liberdade sindical, nos termos do artigo 19, § $6^{\circ}$, também carecem de acionabilidade, estando fora - ao menos diretamente - da jurisdição da Corte Interamericana de Direitos Humanos.

Além da carência na justiciabilidade (aqui haurida como déficit na efetivação por meio de instrumentos de justiça aplicada), a diferença expressiva do número de países que ratificaram os protocolos sobre direitos econômicos demonstra quão arredios são os Estados em engajar-se no cumprimento desses direitos.

Ainda na lição da professora Flávia Piovesan, quatro são as principais vertentes para o futuro do sistema interamericano: 1- adoção, pelos Estados, de legislação interna relativa à implementação de decisões internacionais; 2- previsão de sanção ao Estado que descumprir as decisões internacionais; 3- permitir o acesso direto dos indivíduos à Corte; 4- funcionamento permanente da Comissão e da Corte (PIOVESAN, 2004, p. 16-18). Nesse sentido, importa destacar que o fortalecimento do sistema é o fortalecimento dos regimes locais e dos Estados Democráticos de Direito Constitucionais, haja vista o importante e frutífero intercâmbio que estes diálogos propiciam.

Essa imbricação projeta-se nos diálogos e aberturas de expansão dos sistemas de direitos humanos, e na consolidação da sua indissociabilidade das noções de paz e democracia. Flávia Piovesan é categórica ao afirmar que "não há direitos humanos sem democracia, tampouco democracia sem direitos humanos. Vale dizer, o regime mais compatível com a proteção dos direitos humanos é o regime democrático” (PIOVESAN, 2004, p. 16). A consolidação da democracia é um componente fortificante da lógica dos direitos e encontra identificação direta com a construção da paz. Valer-se do direito e não da força - daí o componente pacífico - é ao mesmo tempo início e 
iniciado pelo restabelecimento das instituições democráticas que, por sua vez, funcionam melhor para prevenir e punir a combustão e a violação dos direitos humanos.

É pautada no ânimo dialógico acima delineado e com base nesta carga normativo-axiológica de fortalecimento da tríade indissociável direitos humanos, democracia e paz que a experiência do sistema interamericano aporta no contexto colombiano e contribui para pôr em marcha o processo de paz em evidência.

Conforme entoa a doutrina:

\begin{abstract}
A jurisprudência do sistema interamericano foi importante e exerceu influência sobre o tema da desmobilização dos paramilitares na Colômbia não só durante a discussão das leis sobre esse tópico, ao ser mobilizada pelas ONGs e demais atores críticos aos projetos de lei da alternatividade penal e de justiça e paz, mas também quando da decisão da Corte Constitucional na sentença C-370/2006. Esse arcabouço normativo deu aos grupos de direitos humanos a possibilidade de reclamar e exigir que a desmobilização não fosse simplesmente um processo de indulto e impunidade, enquanto forneceu aos juízes constitucionais um rol mais amplo de princípios e ferramentas legais para alterar a política preferida pelo Executivo e por sua bancada majoritária no Congresso. (BERNARDI, 2013, p. 162).
\end{abstract}

Consoante acima anunciado, o recorte de casos eleitos - a título exemplificativo e não exaustivo - tem como condão demonstrar de que modo os julgados da Corte contribuíram para o fortalecimento da cultura de direitos naquele Estado e impactaram diretamente no processo de paz alcançado.

\title{
3 VERSUS COLÔMBIA: RECORRÊNCIA DE CASOS RELEVANTES
}

Conforme acima explicitado à luz das previsões convencionais, os Estados partes da Convenção Americana de Direitos Humanos possuem obrigação tanto de respeitar e garantir os direitos humanos quanto, quando for o caso, de providenciar as reparações às vítimas. Nesse sentido, a Corte Interamericana - doravante também nominada de Corte IDH -, nos termos da Convenção Americana - doravante também nominada de CADH -, ordena ao Estado quanto às medidas de reparação a serem tomadas visando pôr fim às violações. Ainda nesses termos, esclarece Pasqualucci que o dever de reparação às violações de direitos humanos incumbe primeiramente aos Estados. No entanto, na ausência de medidas internas adequadas ou suficientes, recorre-se ao Sistema Interamericano (PASQUALUCCI, 2014, p. 188-189).

Ocorrida a condenação do Estado e tendo a Corte estabelecido as medidas de reparação cabíveis, possui o Estado obrigação de observar integralmente a sentença. Assim, as autoridades domésticas restam vinculadas pela decisão da Corte, podendo as medidas serem direcionadas ao Legislativo, Executivo ou Judiciário do país (PASQUALUCCI, 2014, p. 299-300). Mais importante 
que o ato condenatório é o diálogo multinível que se instaura entre os sistemas locais e regional a fim de fortalecer a cultura de direitos humanos na região.

Visando assegurar o cumprimento das medidas de reparação indicadas, a Corte IDH monitora o Estado mediante a submissão de relatórios e audiências públicas e privadas (PASQUALUCCI, 2014, p. 303-305). Somente a partir do monitoramento minucioso do compliance por parte do Estado é que haverá cumprimento integral das sentenças proferidas pela Corte.

O objetivo do sistema é trabalhar com leading cases que promovam um impacto não apenas na vida das vítimas do caso, mas alterem a realidade semelhante em todo o território americano. A jurisprudência americana é propositadamente mais invasiva que aquela do sistema europeu, dando, em certos casos, pouca margem de apreciação aos Estados e tendo como objeto mudanças estruturais do direito e da sociedade. Foi justamente com este ânimo que os casos colombianos foram trazidos ao sistema pela Comissão Interamericana de Direitos Humanos - doravante também CIDH - e julgados pela Corte, conforme abaixo se descreve.

Cumpre alertar que a eleição dos casos não esgota toda a jurisprudência do sistema e foi feita de modo qualitativo, de modo a prestigiar aqueles julgados que se detiveram mais atentamente sobre os casos tangentes do conflito interno e da necessidade de transição à paz. A apresentação dos casos, por opção expositiva, seguirá o critério cronológico.

\section{A) Caso Las Palmeras versus Colômbia}

O primeiro caso analisado, Las Palmeras vs. Colômbia (CIDH, 2001, 2004a, 2008a, 2009a, 2010), diz respeito a fatos datados de 23 de janeiro de 1991, quando membros da Polícia Nacional, com o auxílio de tropas do exército, conduziram operação em Las Palmeras. No contexto da referida operação, ao menos seis pessoas foram executadas extrajudicialmente por forças armadas que atiraram de um helicóptero. Neste escopo, a Polícia Nacional apresentou o corpo de sete pessoas, seis das quais civis e uma sétima, cuja causa mortis não foi confirmada. Agravando-se a situação, os policiais e militares envolvidos nas execuções não foram responsabilizados pelos atos que incorreram 
em graves violações a direitos humanos, sendo que os procedimentos criminais militares perante a justiça interna não progrediram.

Fixada a responsabilidade internacional do Estado pelas violações aos artigos 4, 8 e 25, combinados com o artigo 1.1 da Convenção, a Corte estabeleceu que o Estado colombiano deveria, em síntese, para além da realização de compensações pecuniárias estabelecidas na sentença ${ }^{10}$ :

i) Concluir o processo penal em curso em relação aos fatos que levaram à morte das vítimas que ocasionara a violação da $\mathrm{CADH}$, bem como identificar e punir os responsáveis e publicar o resultado do processo;

ii) Tomar as diligências necessárias para identificar a sétima vítima, bem como empregar todos os meios necessários para localizar seus familiares;

iii) Publicar no Diário Oficial e em um boletim de imprensa da Polícia Nacional e das Forças Armadas Colombianas a sentença de mérito de 6 de dezembro de 2001 e a Sentença de Reparações e Custas;

iv) Devolver os restos da vítima Hernán Lizcano Jacamanejoy a seus familiares, para que estes pudessem proporcionar uma sepultura adequada;

Na primeira resolução da Corte IDH, em novembro de 2004, sobre o cumprimento das medidas impostas ao Estado, a Corte entendeu que a Colômbia cumpriu com duas das treze recomendações do julgamento de Reparações da Corte em novembro de 2002. Neste sentido, o Estado publicou, no Diário Oficial e em revista de imprensa da Polícia Nacional e das Forças Armadas da Colômbia, a sentença de mérito do presente caso, como também devolveu aos familiares de uma das vítimas os restos mortais para que lhes dessem adequada sepultura.

Na segunda supervisão de cumprimento de sentença, em agosto de 2008, a Corte decidiu que o Estado havia parcialmente cumprido com o primeiro ponto do julgamento de reparações, no que diz respeito às diligências realizadas para investigar o presente caso e identificar os responsáveis. No entanto, estabeleceu que continuaria a monitorar as medidas tomadas pelo Estado, pois ainda restariam pendente de análise as medidas tomadas para identificar, dentro de prazo aceitável, a sétima vítima.

Ato contínuo, em dezembro de 2009 a Corte convocou uma audiência para que o Estado prestasse informações completas e atualizadas sobre o cumprimento dos pontos pendentes. Neste momento, com relação à sétima vítima (N.N./Moisés), o Estado informou que continuava trabalhando para localizar os seus restos mortais, mas que não havia obtido resultados positivos. A Corte não

\footnotetext{
${ }^{10}$ O Estado foi condenado ao pagamento de US\$ 100.000,00 (cem mil dólares) a serem entregues aos familiares de N.N./Moisés; US\$ 139.000,00 (cento e trinta e nove mil dólares) correspondentes à compensação de dano em relação aos artigos 8 e 25 da CADH; US\$ 14.500,00 (quatorze mil e quinhentos dólares) em relação aos familiares de Hernán Lizcano Jacanamejoy; US\$ 50.000,00 (cinquenta mil dólares) à Comissão Colombiana de Juristas e US\$ 1.000,00 (mil dólares) ao CEJIL. CORTE INTERAMERICANA DE DIREITOS HUMANOS (CIDH). Caso Las Palmeras Vs. Colômbia. Supervisão de Cumprimento de Sentença. Resolução da Corte Interamericana de Direitos Humanos de 4 de agosto de 2008, p. 2.1-2.9. Disponível em: <https://goo.gl/CQa6r8>. Acesso em: 6 set. 2017.
} 
constatou informação suficiente para evidenciar um avanço real e significativo na determinação da identidade, localização e entrega dos restos de N.N./Moisés a seus familiares, assim como do pagamento de indenização cabível. Passados sete anos da emissão da sentença de reparações e sem que todos os pontos tivessem sido cumpridos pelo Estado, a Presidência achou por bem convocar mais uma audiência privada.

Em resolução de fevereiro de 2010, por fim, a Corte analisou as tentativas do Estado de completar as investigações dos fatos do caso e publicar os resultados e decidiu que o Estado não ofereceu informações completas para o monitoramento do cumprimento de sentença.

Quanto à obrigação de publicar os resultados do processo penal interno referentes aos responsáveis pelas violações, o Estado informou que publicou as sentenças penais de primeira e segunda instância na página web do Ministério de Relações Exteriores, da Polícia Nacional, do Ministério da Defesa e da Vice-Presidência da República. Ademais, com relação aos sítios web do programa presidencial de direitos humanos da Vice-Presidência e do Ministério das Relações Exteriores, serão publicadas de maneira permanente as sentenças da Corte IDH que digam respeito à Colômbia. Ainda, na página da Polícia Nacional, decidiu o Estado pela criação de um link permanente em que ficam disponíveis as sentenças pertinentes.

Nada obstante o parcial cumprimento pelo Estado das medidas de reparação, o monitoramento do cumprimento de sentença permanece em aberto para o Caso Las Palmeiras.

\section{B) Caso 19 Comerciantes versus Colômbia}

Em 1984 um grupo chamado Asociación de Campesinos y Ganaderos del Magdalena Medio se estabeleceu no município de Puerto Boyacá. A região passou então a ser centro de atividade de disputas entre o exército e os grupos de autodefesa - que recebiam auxílio e suporte do exército contra a guerrilha. À época, a Colômbia vivia em declarado estado de emergência.

Os 19 comerciantes, vítimas do presente caso, trabalhavam realizando atividades como transporte de mercadorias entre fronteiras e a sua venda em cidades colombianas. A liderança do mencionado grupo paramilitar decidiu executar os comerciantes, roubando suas mercadorias e veículos como medida de retaliação, tendo em vista que os comerciantes não pagavam os "impostos" cobrados pelo grupo na região. Assim, em outubro de 1987, 17 comerciantes foram detidos e mortos, tiveram seus corpos desmembrados e jogados ao rio. Quinze dias após o desaparecimento dos 17 comerciantes, dois homens foram em busca dos desaparecidos e, com eles, os mesmos fatos se repetiram. 
Agravando-se as violações, as autoridades estatais não tomaram medidas imediatas para realizar a busca dos desaparecidos, em grande parte porque os grupos paramilitares recebiam colaboração e apoio das autoridades militares. Com relação ao processo criminal, duas pessoas foram condenadas por serem autoras do crime de homicídio, duas por atuarem como cúmplices e uma por sequestro. Com relação aos dois comerciantes executados posteriormente, não houve, por falta de provas, condenados pelos crimes.

Diante do exposto, o Estado foi condenado, em sentença de 5 de julho de 2004 (CIDH, 2004b), para além do pagamento de indenizações, custas e gastos, a

i) Investigar efetivamente os fatos do caso, identificando e julgando todas as pessoas envolvidas nas violações cometidas, sendo o resultado do processo publicamente julgado;

ii) Efetuar, em prazo razoável, buscas para determinar o ocorrido com os restos das vítimas e entregar, no que possível, às famílias;

iii) Erguer monumento em memória das vítimas e mediante cerimônia pública e em presença dos familiares das vítimas, colocar uma placa com o nome dos 19 comerciantes;

iv) Realizar ato público de reconhecimento de sua responsabilidade internacional em relação aos fatos do caso, na presença dos familiares das vítimas e contando com a participação das mais altas autoridades do Estado;

v) Fornecer gratuitamente tratamento médico e psicológico requerido pelos familiares das vítimas;

vi) Estabelecer as condições necessárias para que os membros da família da vítima Antonio Flórez Contreras, que estão em exílio, possam regressar à Colômbia e

vii) Garantir a vida, integridade e segurança das pessoas que prestaram depoimentos para a Corte, bem como suas famílias.

Na supervisão de cumprimento de sentença de fevereiro de 2006 (CIDH, 2006a), restou constatado que o Estado organizou ato público, com a presença de alta autoridade do Estado, para reconhecimento da responsabilidade internacional. Informou a Colômbia, ainda, que em maio de 2005 o Promotor Público especializado na unidade de direitos humanos e direito internacional humanitário incluiu o julgamento da corte no "case file” que está acompanhando. Alega que o fato em si tem natureza reparatória porque prova a interiorização da decisão internacional. Ainda, com relação à busca pelos restos das vítimas, a Promotoria alegou que reabriria as investigações.

No entanto, entendeu a Corte que as medidas como a localização de familiares e efetiva investigação do caso para identificar, punir e processar os atores das violações, bem como a disseminação pública dos resultados, não foram devidamente cumpridas pela Colômbia, razão pela qual permaneceria acompanhando as medidas adotadas pelo Estado.

Em novembro de 2008 (CIDH, 2008b), em resolução de cumprimento de sentença, a Corte constatou que o Estado informou que em março de 2008 a Sala de Cassação Penal da Corte Suprema de Justiça emitiu decisão em que se declarou sem validade o feito processado pela justiça penal militar 
e a resolução de cessação do procedimento, assim como pugnou pela continuação das investigações. O Estado ressaltou a importância da sentença para proteção de direitos humanos na Colômbia.

Em resolução de julho de 2009 (CIDH, 2009b), a Corte reconheceu a informação prestada pelo Estado de que, em maio de 2008, a Sala de Cassação Penal da Corte Suprema de Justiça emitiu decisão sem precedentes no país. Na referida decisão, foi declarada sem validez a decisão da justiça penal militar, ordenando-se a reabertura da investigação em sede da justiça ordinária. A Corte entendeu tal decisão como passo importante, ressaltando seu valor jurisprudencial e relevante medida para combater a impunidade, abrindo caminho para responsabilização de membros estatais que violem direitos.

Quanto à obrigação de oferecer gratuitamente tratamentos médicos e psicológicos requeridos pelos familiares das vítimas, ainda que tardiamente, informou o Estado que a medida está sendo cumprida em conjunto com outras sentenças emitidas pela Corte, sendo que as informações foram enviadas no marco da supervisão de cumprimento de sentença do caso Massacre de Pueblo Bello.

Assim, em fevereiro de 2012, a Corte emitiu resolução a fim de convocar audiência privada tratando especificamente das medidas de reparação sobre atenção médica e psicológica ordenadas em casos envolvendo a Colômbia, entre eles os casos 19 Comerciantes, Masacre de Mapiripán e Masacre de Pueblo Bello.

Em junho de 2012, com relação à recomendação de efetuar em um prazo razoável uma busca dos restos das vítimas, o Estado informou que o Centro Único Virtual de Identificação apoiaria a Fiscalía em sua atividade - o Centro executaria um "Plano nacional de busca de pessoas desaparecidas” (CIDH, 2012a, p. 18). O Estado apontou que enviou cópia do documento à Corte no marco da supervisão do cumprimento de sentença no Caso do Massacre de Mapiripán vs. Colômbia, o qual será analisado em seguida.

Em junho de 2016, a Corte reconheceu a decisão da Corte Constitucional colombiana ${ }^{11}$ que considerou possível exigir o cumprimento e ordenar a execução de disposições internacionais, assinalando a possibilidade de exigir e impor às autoridades públicas o cumprimento das medidas de reparação da Corte IDH, bastando que se comprove que as medidas não foram satisfeitas (CIDH, 2016, p. 9).

\footnotetext{
${ }^{11}$ COLÔMBIA. Quinta Sala de Revisão da Corte Constitucional Colombiana. Sentença no T-653/12. Colômbia, 23 ago. 2012.
} 
Nada obstante os importantes passos tomados pelo Estado colombiano, a Corte IDH entendeu que não foi dado integral cumprimento às medidas de reparação, sendo que o cumprimento de sentença do presente caso permanece em aberto.

\section{C) Caso Massacre de Mapiripán versus Colômbia}

No mesmo contexto de luta contra grupos guerrilheiros insere-se o presente caso, em que o Estado colombiano impulsionou a criação de grupos de autodefesa visando auxiliar as forças públicas em operações contra os grupos guerrilheiros. Nesse sentido, em julho de 1997, aproximadamente 100 membros das Autodefesas Unidas da Colômbia (AUC), utilizando vestimentas de uso das forças armadas e portando armas de monopólio estatal, torturaram e assassinaram 49 pessoas que haviam sido privadas de liberdade, destruindo seus corpos e os jogando ao Rio Guaviare, no Município de Mapiripán.

A Corte IDH concluiu que, a despeito das circunstâncias difíceis pelas quais passava a Colômbia, elas não eximem o Estado de cumprir suas obrigações oriundas da CADH, as quais subsistem em casos como este. Portanto, o Estado foi condenado a:

i) Investigar os fatos do caso, identificar, julgar e punir os responsáveis;

ii) Identificar e individualizar as vítimas do Massacre e seus familiares;

iii) A instauração de um mecanismo oficial de acompanhamento do cumprimento das reparações;

iv) Prover aos familiares das vítimas executadas e desaparecidas tratamento de saúde;

v) A instituição de garantias estatais em prol da segurança dos ex-habitantes do Município de Mapiripán que desejem regressar;

vi) A construção de um monumento apropriado e digno para recordar dos fatos;

vii) A implementação de um programa de educação em direitos humanos e direito internacional humanitário presente nas forças armadas, em todos os níveis hierárquicos;

viii) A publicação de sentença da Corte no Diário oficial e em outro diário de circulação nacional;

No tocante às medidas acima colacionadas, em 26 de novembro de 2008 (CIDH, 2008c), em supervisão de cumprimento de Sentença, a Corte constatou que o Estado criou um mecanismo oficial para cumprir com as reparações a que foi condenado, o M.O.S Mapiripán. Neste aspecto, os peticionários informaram que de fato os mecanismos haviam sido criados com participação dos representantes e postos em funcionamento.

Quanto à obrigação de realizar diligências para individualizar e identificar as vítimas executadas e desaparecidas, as ações foram levadas a cabo no escopo do M.O.S, e foram realizadas pela Fiscalía General de la Nación. Também com relação à obrigação de realizar ações necessárias 
para garantir a segurança dos familiares das vítimas, o Estado criou um plano de ação, mas não teve sucesso, pois as vítimas tinham medo de retornar.

Em supervisão de cumprimento de sentença de 8 de julho de 2009, constatou-se que o Estado reforçou o plano de ação do M.O.S., uma maneira exemplar de supervisionar o cumprimento de medidas ordenadas pela Corte (CIDH, 2009b, p. 3). Ademais, a Fiscalía General da la Nación, mediante auxílio da Unidad Nacional de Derechos Humanos, vinculou 30 pessoas, realizou 18 acusações e 13 condenações em relação aos envolvidos no presente caso. Não obstante, a Corte IDH entendeu que subsistia a impunidade e faltavam medidas concretas para acabar com a situação de impunidade existente.

Em 2008 foi criado comitê tripartite de atenção à população deslocada. Os representantes valoraram a criação como positiva, porém insuficiente.

Quanto à obrigação de implementar programa de educação em direitos humanos, a Colômbia anunciou que firmou convênio de cooperação com o Alto Comissariado das Nações Unidas para os Direitos Humanos. No exército foi criada a chefia de direitos humanos, bem como um convênio de cooperação com o Instituto Interamericano de Direitos Humanos para supervisionar o progresso da matéria. A educação em direitos humanos é essencial enquanto medida de não repetição dos fatos.

Como resultado, em março de 2011, o Estado, juntamente com os representantes, assinou acordo composto pelos representantes das vítimas, o Diretor da Direção de Direitos Humanos e DIH do Ministério de Relações Exteriores e o Chefe da Oficina de Cooperação e Relações Internacionais do Ministério da Proteção Social. Nada obstante, foi convocada audiência privada devido à omissão do Estado em prestar informações sobre atenção médica e psicológica ordenada como reparação.

Com relação à supervisão de 23 de novembro de 2012 (CIDH, 2012c), o Estado esclareceu que, para cumprir a recomendação de identificação de outras vítimas, as diligências foram tomadas pela Direção Nacional de Direitos Humanos e DIH e pela Unidad Nacional de Fiscalías para la Justicia y la Paz, da Fiscalía General de la Unión. Ainda, reconheceu os fatos ocorridos, esclarecendo que continuará cumprindo de boa-fé com o ordenado pela Corte. Assim, o procedimento de supervisão de cumprimento de sentença permanece em aberto, tendo em vista que há pontos da sentença ainda pendentes de integral cumprimento.

\section{D) Caso Massacre de Pueblo Bello versus Colômbia}

Seguindo a cronologia das decisões da Corte IDH, passa-se à análise do caso Pueblo Bello, cuja sentença data do ano de 2006. Apresentando fatos análogos aos acima delineados, o conflito 
ocorrido em Pueblo Bello envolve novamente atos violentos realizados por grupos paramilitares. Nesse sentido, as violações de direitos humanos ocorridas no caso se deram em janeiro de 1990, quando um grupo de aproximadamente sessenta homens fortemente armados, pertencentes à organização paramilitar chamada Los Tangueros, liderados por Fidel Antonio Castaño Fil, entraram na aldeia de Pueblo Bello, com o objetivo principal de saquear e sequestrar membros da comunidade.

O grupo armado estava fortemente armado, vestia roupas civis e uniformes de uso privado das Forças Armadas. Os paramilitares saquearam algumas casas, maltratando seus ocupantes, sendo que um número indeterminado de homens foi levado para a praça da cidade. Lá chegando, com base em uma lista que carregavam, os guerrilheiros escolheram 43 homens, supostas vítimas neste caso, os quais foram amarrados, amordaçados e forçados a adentrar nos caminhões utilizados para o transporte. Os prisioneiros foram levados à fazenda Santa Monica, onde foram recebidos por Fidel Castaño Gil, o qual ordenou o interrogatório e tortura das vítimas, que foram mortas violentamente e, algumas, enterradas em Las Tangas. Apenas seis das 43 supostas vítimas foram identificadas e os seus restos mortais retornaram às suas famílias. Outras 37 pessoas continuam desaparecidas.

Como medidas de reparação, além da indenização pecuniária aos familiares das vítimas (CIDH, 2006, Anexos I e II), a Corte IDH determinou, em síntese:

i) Realizar imediatamente e em prazo razoável a conclusão eficaz de investigações que delimitem os responsáveis pelas ações e omissões dos fatos narrados;

ii) Adotar medidas para que as violações ocorridas sejam devidamente processadas e julgadas, sendo garantidas as medidas judiciais cabíveis para que haja reparação do ocorrido em Pueblo Bello;

iii) Identificar imediatamente o paradeiro dos restos morais das vítimas para que suas famílias possam realizar o enterro apropriado, respeitando as normativas internacionais condizentes à busca e identificação de pessoas desaparecidas e utilizando todo conhecimento científico e aparato institucional necessário para que sejam encontradas;

iv) Promover tratamento médico adequado aos familiares das vítimas pelo tempo necessário;

v) Garantir a segurança dos familiares das vítimas para que possam retornar a viver em Pueblo Bello, caso queiram;

vi) Realizar um ato público de reconhecimento de responsabilidade internacional das violações elencadas, realizando o desagravo às vítimas desaparecidas e mortas, bem como a seus familiares;

vii) Construir um monumento apropriado e digno para recordar o massacre de Pueblo Bello.

Após a publicação da referida sentença, tanto o Estado colombiano quanto os representantes das vítimas solicitaram à Corte IDH, em novembro de 2006, interpretação da sentença (CIDH, 2006c). Neste momento, o Estado requereu a interpretação acerca do alcance das indenizações aos familiares a título de reparação, bem como solicitou esclarecimentos acerca do programa habitacional a ser desenvolvido em benefício aos familiares das vítimas. Já os representantes das vítimas 
apresentaram dúvidas relacionadas com a determinação dos beneficiários das indenizações. Tal medida já demonstra o comportamento mais diligente do Estado colombiano em realizar a correta reparação das vítimas, o que, diferentemente dos casos anteriormente analisados, apresenta uma melhora no comportamento estatal em adequar sua atuação ao Sistema Interamericano de Direitos Humanos.

Ainda assim, posteriores resoluções de cumprimento de sentença advieram nos anos de 2008, 2009 e 2012 (CIDH, 2008d, 2009c, 2012d). Como ponto resolutivo da primeira manifestação sobre o cumprimento de sentença, publicada em 2008 (CIDH, 2008d), a Corte IDH convocou audiência com o propósito de obter maiores informações do Estado acerca do cumprimento das medidas de reparação, considerando que, de acordo com as alegações das partes, pouco havia sido feito. Os pontos mais controvertidos nessa primeira análise se deram em torno das informações prestadas pelo Estado, as quais não foram consideradas atualizadas e demonstraram certa morosidade no cumprimento das medidas de reparação.

No tocante à supervisão de cumprimento de sentença publicada no ano de 2009 (CIDH, 2009c), após a referida audiência estabelecida em resolução anterior, o Estado não apresentou evoluções no que tange à obrigação de investigar os fatos e sancionar os responsáveis. No entanto, no tocante à busca e identificação das vítimas desaparecidas, esforços e avanços do Estado foram reconhecidos. Ainda, com relação ao tratamento psicológico das vítimas, a Corte considerou a morosidade em se efetuar a medida. Já em relação às indenizações e demais medidas, a Corte considerou positiva a audiência realizada (CIDH, 2009c, p. 26) para que se pudesse estabelecer parâmetros adequados de cumprimento, os quais ainda aguardavam realização.

Por fim, na última supervisão de cumprimento de sentença apresentada em 2012 (CIDH, 2012d), a Corte decidiu convocar novamente uma audiência privada para que o Estado apresentasse pontos resolutivos concretos. Mesmo assim, o procedimento de supervisão de cumprimento de sentença permanece em aberto, tendo em vista que há pontos da sentença ainda pendentes de integral cumprimento, demonstrando a morosidade estatal.

\section{E) Caso Massacre de Santo Domingo versus Colômbia}

O próximo caso apresentado em sequência cronológica de análise pela Corte IDH teve como palco o vilarejo de Santo Domingo, localizado no nordeste da Colômbia. O contexto da região é complexo, assim como os demais casos já analisados, abrangendo uma série de conflitos armados e disputas territoriais. As violações cometidas ocorreram em meados de dezembro de 1998, quando o 
Exército Colombiano tomou conhecimento de que um avião pousaria clandestinamente na região de Santo Domingo com carregamento de armas destinadas à guerrilha das Forças Armadas Revolucionárias da Colômbia (FARC). Mesmo sabendo do grande fluxo de pessoas que, em decorrência de um evento esportivo, circulavam no local, o Exército colombiano desferiu bombas na rua principal do vilarejo de Santo Domingo, seguidas de ataques por metralhadoras. Tal investida militar provocou a morte de 17 pessoas, incluindo seis crianças, e deixou feridas 27 pessoas, entre elas 10 crianças. Ainda, o incidente causou o deslocamento dos moradores do vilarejo para cidades vizinhas, deixando Santo Domingo deserta até meados de janeiro de 1999, quando os sobreviventes iniciaram o retorno à região.

Em sua defesa, o Estado colombiano apresentou exceções preliminares alegando a incompetência ratione materiae, bem como o não esgotamento dos recursos internos. Dessa feita, o Estado advogou pela inadmissibilidade da demanda, tendo em vista que os fatos circundavam possíveis violações de normas de Direito Internacional Humanitário, por se tratar de conflito armado, não abrangendo o rol jurisdicional da Corte IDH. Ademais, elucidou que os incidentes ocorridos em Santo Domingo estavam sendo apurados em processo contencioso administrativo, em jurisdição interna, e que, portanto, os recursos internos não se haviam esgotado.

A Corte IDH negou provimento à primeira exceção preliminar, pois, apesar de o rol de apreciação jurisdicional ser taxativo, outros dispositivos internacionais podem ser utilizados para dar embasamento à fundamentação e análise do mérito. Assim, a Corte IDH reiterou que a CADH pode e deve ser interpretada à luz de outros tratados e convenções, principalmente as normas de DIH, no caso concreto (CIDH, 2012e, p. 10).

Como medidas de reparação, após condenar o Estado pelas violações perpetradas aos artigos 4, 5, 19, 21 e 22 da CADH, todos cumulados com o artigo 1.1 do mesmo diploma, a Corte IDH determinou:

i) Que a própria sentença de exceções preliminares, mérito, reparações e custas é, per se, uma reparação às vítimas;

ii) Que o Estado deve realizar um ato público reconhecendo sua responsabilidade internacional frente aos fatos do caso;

iii) Que o Estado disponibilize um resumo da sentença em diário oficial e em veículo de ampla circulação nacional, bem como publique a sentença integral em site oficial;

iv) Que o Estado forneça tratamento médico adequado às vítimas, por meio de instituições médicas adequadas;

v) Que o Estado deve, no prazo de um ano e meio, indenizar de forma célere as vítimas e parentes de vítimas que não foram reparados pela jurisdição administrativa internamente;

vi) Que o Estado deve pagar, a título de custas processuais, o montante de US\$ 5.000,00 (cinco mil dólares), a ser dividido entre as instituições que realizaram a defesa das vítimas;

vii) Que a Corte supervisionará o cumprimento integral da Sentença e dará por concluído o caso após cumpridas todas as medidas de reparação por parte do Estado; 
Após a publicação da referida sentença, os representantes das vítimas solicitaram interpretação dos pontos resolutivos (CIDH, 2013a) sem que, no entanto, fosse encerrado o procedimento de supervisão de cumprimento de sentença, o qual continua em aberto.

\section{F) Caso Operação Génesis versus Colômbia}

Os fatos ocorreram na segunda metade da década de 1990, quando grupos armados paramilitares e guerrilhas espalharam-se pelo território de Urabá Chocoano. Em decorrência da presença hostil de guerrilhas, acompanhada de ameaças, desaparecimentos forçados, assassinatos, houve deslocamento forçado em massa da população afro-colombiana que residia no local.

Não bastasse isso, entre os dias 24 e 27 de fevereiro de 1997, foi levada a cabo a operação militar Génesis, na região dos rios Salaquí e Truandó. O objetivo do cerco era capturar e/ou destruir integrantes das FARC. Ainda, concomitantemente à operação Génesis, grupos paramilitares das Autodefesas Unidas de Córdoba e Urabá (ACCU), na chamada operação Cacarica, empreenderam avanço de norte a sul, partindo do Parque Nacional dos Katios, ao longo do rio Cacarica, passando por Bijao e outras comunidades localizadas às margens dos rios Salaquí e Truandó, onde realizaram operações conjuntas com o exército. Como marco da operação Cacarica os paramilitares executaram Marino López em Bijao, desmembrando seu grupo.

Após as operações, centenas de moradores foram forçados a se deslocar para Turbo, Bocas de Atrato e Panamá, onde permaneceram em diferentes acampamentos durante quatro anos. Muitos retornaram às comunidades que se encontravam em paz na bacia do rio Cacarica. Mesmo assim, muitos continuaram a ser perseguidos, ameaçados e violentados por grupos paramilitares.

Ainda assim, o Estado foi condenado responsável pelas violações dos artigos 4.1, 5.1 e 5.2 c/c 1.1, ante a morte de Marino López Mena. A Corte ainda concluiu que as ações ao longo da bacia do rio Cacarica se deram em conjunto e colaboração entre o Estado - operação Génesis - e os grupos paramilitares que impulsionaram a operação Cacarica. Assim, o Estado violou os artigos 5, 19 e 1.1 da $\mathrm{CADH}$, em prejuízo das crianças deslocadas e daquelas que nasceram no curso do deslocamento. Com relação à desapropriação do território ancestral das comunidades afrodescendentes, o Estado foi responsabilizado pela violação ao artigo 21 e 1.1, por violar o direito de propriedade coletiva em prejuízo do Conselho das Comunidades da Bacia do Rio Cacarica (CIDH, 2013b).

No tocante às garantias e proteções judiciais, a Corte considerou que o Estado reconheceu parcialmente sua responsabilidade pela violação do prazo razoável para investigações internas, o qual 
não condiz com o disposto no artigo 8 da CADH. Ante a comprovação de que alguns fatos foram apurados e outros não, a Corte responsabilizou o Estado por não haver realizado com a devida diligência as investigações acerca da participação de agentes estatais e estruturas paramilitares, mesmo após a condenação de um oficial de alta patente do Exército em jurisdição interna. A Corte também condenou o Estado pela violação aos artigos 25.2.a e 25.2.c da CADH em prejuízo das comunidades afrodescendentes (CIDH, 2013b).

Em supervisão de cumprimento de sentença, publicado recentemente, no ano de 2016 (CIDH, 2016), a Corte reforçou os pontos resolutivos da sentença de mérito, quais sejam:

i) Continuar de forma eficaz e com as investigações de diligência abertas, e abrir as necessárias, a fim de identificar, processar e punir todos os responsáveis pelos fatos deste caso e remover todos os obstáculos, de facto e jure, que possam manter a impunidade;

ii) Realizar um ato público de reconhecimento de responsabilidade internacional para os fatos do presente caso;

iii) Fornecer tratamento médico adequado e prioridade exigida pelas vítimas neste caso, no contexto de programas de reparação nos termos da regulamentação nacional;

iv) Restituir o uso, gozo e posse eficaz dos territórios reconhecidos na legislação nacional para comunidades afrodescendentes agrupadas no Conselho das Comunidades da Bacia do Rio Cacarica;

v) Assegurar que os territórios restituídos às vítimas neste caso, bem como o local onde vivem atualmente, sejam adequados, seguros e garantam vida digna tanto para aqueles que retornaram, quanto àqueles que ainda não o fizeram;

vi) Garantir que todas as pessoas que foram reconhecidas como vítimas no julgamento realmente recebam a indenização prevista pelos regulamentos internos relevantes;

vii) Pagar os montantes estabelecidos no julgamento por danos pecuniários e não pecuniários causados ao Sr. Marino López Mena e suas famílias, para os quais devem ser realizadas as emissões e publicações relevantes; e

viii) Pagar os montantes estabelecidos para reembolso de custas.

Ademais disso, ante à recente manifestação da Corte IDH ao presente caso analisado, inferese que o procedimento de supervisão de cumprimento de sentença continua em aberto e aguardando manifestação estatal até o final do mês de fevereiro de 2017.

Percorrido o cardápio exemplificativo dos casos acima brevemente explanados, da análise das sentenças, bem como das resoluções emitidas pela Corte no que diz respeito à análise de seu cumprimento, constata-se, primeiramente, a importância das decisões da Corte IDH condenatórias do Estado, por si só, como medidas de reparação às vítimas e um avanço na construção de uma maior preocupação com os direitos humanos. Depreende-se do analisado que as medidas impostas ao Estado servem para reforçar maior preocupação com os direitos humanos, evitar repetição dos fatos, como também conservar a memória das vítimas (CIDH, 2016, p. 3). Adicionalmente, a publicação de resultados dos processos penais internos no que respeita aos responsáveis pelas violações, como ocorreu no Caso Las Palmeras, apresenta-se igualmente como passo à consolidação de um Estado de 
Direito, como também a medida condenatória de levar a cabo a responsabilização dos autores das violações.

As sentenças da Corte IDH, somadas às resoluções de cumprimento de sentença, levaram ainda o Estado colombiano a coordenar esforços para resolver problemas recorrentes de violações de direitos humanos comuns aos casos analisados, como se percebe, pela análise conjunta levada a cabo em sete casos quanto à medida de reparação de prestação de saúde e atendimento psicossocial. A pressão exercida pela Corte IDH, que levou o Estado a tomar ditas medidas, fortalece a possibilidade de reparação às vítimas de direitos humanos no país.

Ademais, outra medida criada e impulsionada pelos mandamentos da Corte, e salutar no cumprimento de suas condenações, diz respeito ao plano criado pelo Estado colombiano no caso do Massacre de Mapiripán, no marco do programa M.O.S, anteriormente citado. A partir de tal medida, constatam-se esforços para identificar vítimas e familiares, fortalecendo a possibilidade de reparação e consolidando os direitos humanos no país.

Nada obstante, salienta-se igualmente a decisão da Corte Constitucional colombiana trazida a lume no Caso 19 Comerciantes, em que uma decisão judicial interna estabeleceu importante marco ao apontar que os tribunais internos possuem também competência para exigir o cumprimento de sentenças da Corte IDH (CIDH, 2016, p. 5). Constata-se, assim, a importância do diálogo entre o direito internacional e o direito interno, visando à construção de um Estado de Direito com respeito aos direitos humanos.

Ante referida análise, percebe-se que as condenações do Estado colombiano perante o Sistema Interamericano tiveram, per se, caráter positivo na construção de uma cultura dos direitos humanos no país. Em que pese a morosidade do trâmite processual perante a CIDH, após o encaminhamento do relatório de mérito à Corte IDH para processamento em jurisdição internacional, a postura estatal se torna claramente mais atenta e rígida.

Nesse sentido, os três primeiros casos analisados se mostram mais sintomáticos, pois exigiram uma postura muito mais ativa da Corte IDH no que tange ao chamamento do Estado para prestar esclarecimentos de cumprimento de sentença. Essa preocupação da Corte IDH em acompanhar a atuação estatal, mesmo que de fato implique um cumprimento muitas vezes parcial por parte do Estado, pode ser considerada de grande valia, pois apresenta alternativas para a inserção dos direitos humanos nas instituições internas.

É curioso ainda salientar que, nas três últimas sentenças analisadas, o cumprimento por parte do Estado se mostrou mais efetivo, ainda que não standard. Ademais, a Corte IDH tem se mostrado cada vez mais célere na manutenção do diálogo com o Estado colombiano, deixando-o menos 
confortável em descumprir os postulados em jurisdição regional internacional. Assim, os esforços realizados pela Corte IDH ao fim da década de 1990 e ao longo dos anos 2000 até a atualidade, no que tange ao caso colombiano, mostram-se deveras efetivos e positivos.

O recorrido dos casos demonstra como o intercâmbio dialógico entre Corte IDH e o Estado Colombiano, ainda que pautado pela ótica repressiva das violações, lançou luz sobre traços estruturais institucionais estatais e promoveu importantes alterações paradigmáticas, contribuindo com o fortalecimento dos direitos humanos e possibilitando o processo de paz colombiano.

\section{NOTAS DE CONCLUSÃO: UM (RE)COMEÇO PARA A COLÔMBIA}

A promoção da paz e a defesa dos direitos humanos são duas faces da mesma moeda e, por sua vez, ambas retroalimentam a própria noção de Estado Democrático de Direito. Direitos Humanos, Democracia e Paz - ainda que sejam signos de significados cambiantes - são a tríade que sustenta o discurso internacional contemporâneo.

A criação das Nações Unidas, que, uma vez que produziu importantes transformações na ordem internacional e interna, é divisor de águas na seara internacional, inaugurou, no plano internacional, uma nova etapa protetiva dos direitos humanos na contemporaneidade. A Organização das Nações Unidas inseriu-se no cenário internacional com a Carta de São Francisco, datada de 1945, que contém, entre as suas disposições, o repto principal da instituição de mantença da paz. Assim, dentro deste objetivo maior, há destaque ao papel dos direitos humanos e da dignidade da pessoa humana como instrumental da preservação das gerações futuras contra o "flagelo da guerra"12. Na atualidade, a proteção dos direitos humanos ocupa espaço fundamental na agenda não só da ONU, mas também de outras esferas de todo âmbito internacional, e tornou-se ao mesmo tempo causa e consequência da mantença da paz e das garantias do rule of law.

A tônica dos direitos humanos substitui o direito da força pela força do direito, com apelo à “lógica multilateralista do diálogo, a legitimidade das negociações e dos consensos internacionais” (PIOVESAN, 2011, p. 54). Novamente, o ânimo dos diálogos emerge como um catalisador da promoção dos direitos humanos, traçando uma ponte entre a jurisdição internacional e aquelas nacionais, deixando de ser uma pauta contra os Estados e sim por eles incorporada. Associa-se a ideia

\footnotetext{
${ }^{12}$ Expressão utilizada no preâmbulo do referido documento que - em seu capítulo primeiro -, ao enunciar os propósitos e princípios das Nações Unidas, deixa claro o main goal da garantia da paz, in verbis: " 1 . Manter a paz e a segurança internacionais e, para esse fim: tomar, coletivamente, medidas efetivas para evitar ameaças à paz e reprimir os atos de agressão ou outra qualquer ruptura da paz e chegar, por meios pacíficos e de conformidade com os princípios da justiça e do direito internacional, a um ajuste ou solução das controvérsias ou situações que possam levar a uma perturbação da paz”. Disponível em: <https://goo.gl/NG8bwr>. Acesso em: 6 set. 2012.
} 
de Estado de Direito com o avanço no processo de justicialização dos direitos humanos internacionalmente enunciados.

No caso colombiano o frutífero diálogo entre os sistemas local e regional possibilitou passos adiante que nos levaram à pavimentação do processo de paz e à consolidação das estruturas institucionais do Estado de Direito. Não é à toa que a Constituição colombiana é hoje exemplo da recepção do direito internacional dos direitos humanos, dando a estes tratados status privilegiado e trabalhando com a ideia de controle de convencionalidade.

A recorrência jurisprudencial do sistema interamericano corrobora com a tríade anunciada. Tendo os casos sob análise palco comum de grave conflito armado não internacional na Colômbia, incidiu o direito internacional dos direitos humanos, mormente a partir das condenações e resoluções de cumprimento de sentença da Corte IDH, no combate às sistemáticas violações reiteradamente cometidas. Percebe-se, no entanto, que inobstante a condenação da Corte incidir especificamente nos direitos humanos violados em cada caso concreto, adotando medidas específicas de reparação, o diálogo fomentado entre as esferas locais e regionais, principalmente na esfera de cumprimento de sentença, fortalece o Estado de Direito e a cultura da paz.

Outrossim, o Sistema Interamericano de Direitos Humanos, principalmente com a atuação da Corte IDH, conforme se depreende da análise dos casos colacionados, permitiu à população colombiana socorrer-se à instância internacional, quando as forças internas se encontravam em iminente impossibilidade de garantia de sua proteção - e por diversas vezes diretamente envolvidas nas violações. Daí a importância das sentenças de condenação da Corte IDH, na medida em que, por si só, apresentam ao mesmo tempo fortalecimento à proteção dos direitos humanos em nível nacional e internacional, reparações às vítimas de graves violações e consequentemente fortalecimento da democracia e de processo de paz em contexto de intricado conflito armado. Assim, com a migração dos direitos humanos, da esfera exclusivamente de soberania constitucional e estatal para a esfera de responsabilidade internacional, incorre-se em novos moldes não só dos direitos humanos e do direito internacional, mas com direta ingerência no direito constitucional.

Resta, destarte, demonstrada a contribuição do Sistema Interamericano de Direitos Humanos, com grande destaque ao seu órgão jurisdicional, para o fortalecimento do processo democrático, da rule of law e da paz no território colombiano. Essas circunstâncias, mais uma vez, destacam a "racionalidade de resistência” (FLORES, 2009, p. 32) dos direitos humanos enquanto plataforma emancipatória (PIOVESAN, 2011, p. 54) que possibilita a transformação da realidade. 


\section{REFERÊNCIAS}

BERNARDI, Bruno Boti. O sistema interamericano de direitos humanos e a lei de justiça e paz na Colômbia: política doméstica e influência de normas internacionais. Contexto int. [online]. 2013, p. 139-172. ISSN 0102-8529. Disponível em: <https://goo.gl/icB8X5>. Acesso em: 6 set. 2017.

CENTRO NACIONAL DE MEMORIA HISTÓRICA. Yo aporto a la verdad, acuerdos de contribución a la verdad y la memoria histórica: mecanismo no judicial de contribución a la verdad, la memoria histórica y la reparación, Ley 1424/2010 / Centro Nacional de Memoria Histórica - Dirección de acuerdos de la verdad. Editor Álvaro Villarraga Sarmiento. Bogotá: Centro Nacional de Memoria Histórica, 2014. Prefácio.

COLÔMBIA. Quinta Sala de Revisão da Corte Constitucional Colombiana. Sentença no T-653/12. Colômbia, 23 ago. 2012.

CORTE INTERAMERICANA DE DIREITOS HUMANOS (CIDH). Caso 19 Comerciantes Vs. Colômbia. Mérito, Reparações e Custas. Sentença de 5 de julho de 2004b. Disponível em: <https://goo.gl/phqcFU>. Acesso em: 6 set. 2017.

CORTE INTERAMERICANA DE DIREITOS HUMANOS (CIDH). Caso 19 Comerciantes Vs. Colômbia. Supervisão de Cumprimento de Sentença. Resolução de 2 de fevereiro de 2006a. Disponível em: <https://goo.gl/fJwCQu>. Acesso em: 6 set. 2017.

CORTE INTERAMERICANA DE DIREITOS HUMANOS (CIDH). Caso 19 Comerciantes Vs. Colômbia. Supervisão de Cumprimento de Sentença. Resolução da Corte Interamericana de Direitos Humanos de 10 de julho de 2007. Disponível em: <https://goo.gl/m1Sm8x>. Acesso em: 6 set. 2017.

CORTE INTERAMERICANA DE DIREITOS HUMANOS (CIDH). Caso 19 Comerciantes Vs. Colômbia. Supervisão de Cumprimento de Sentença. Resolução da Corte Interamericana de Direitos Humanos de 26 de novembro de 2008b. Disponível em: <https://goo.gl/S5kcMk>. Acesso em: 6 set. 2017.

CORTE INTERAMERICANA DE DIREITOS HUMANOS (CIDH). Caso 19 Comerciantes Vs. Colômbia. Supervisão de Cumprimento de Sentença. Resolução da Corte Interamericana de Direitos Humanos de 8 de julho de 2009b. Disponível em: <https://goo.gl/iefkFG>. Acesso em: 6 set. 2017.

CORTE INTERAMERICANA DE DIREITOS HUMANOS (CIDH). Caso 19 Comerciantes Vs. Colômbia. Supervisão de Cumprimento de Sentença. Resolução da Corte Interamericana de Direitos Humanos de 8 de fevereiro de 2012a. Disponível em: <https://goo.gl/GLMXGv>. Acesso em: 6 set. 2017.

CORTE INTERAMERICANA DE DIREITOS HUMANOS (CIDH). Caso 19 Comerciantes Vs. Colômbia. Supervisão de Cumprimento de Sentença. Resolução da Corte Interamericana de Direitos Humanos de 26 de junho de 2016. Disponível em: <https://goo.gl/kGVajt>. Acesso em: 6 set. 2017.

CORTE INTERAMERICANA DE DIREITOS HUMANOS (CIDH). Caso das comunidades afrodescendentes deslocadas da Bacia do Rio Cacarica (Operação Génesis) Vs. Colômbia. Sentença de 20 de novembro de 2013b. Disponível em: <https://goo.gl/xcNgYV>. Acesso em: 6 set. 2017. 
CORTE INTERAMERICANA DE DIREITOS HUMANOS (CIDH). Caso das comunidades afrodescendentes deslocadas da Bacia do Rio Cacarica (Operação Génesis) Vs. Colômbia. Supervisão de Cumprimento de Sentença. Resolução da Corte Interamericana de Direitos Humanos de 20 de outubro de 2016. Disponível em: <https://goo.gl/sgT7J5>. Acesso em: 6 set. 2017.

CORTE INTERAMERICANA DE DIREITOS HUMANOS (CIDH). Caso Las Palmeras Vs. Colômbia. Mérito. Sentencia de 6 de dezembro de 2001. Disponível em: <https://goo.gl/ECDyp2>. Acesso em: 6 set. 2017.

CORTE INTERAMERICANA DE DIREITOS HUMANOS (CIDH). Caso Las Palmeras Vs. Colômbia. Supervisão de Cumprimento de Sentença. Resolução da Corte Interamericana de Direitos Humanos de 17 de novembro de 2004a. Disponível em: <https://goo.gl/hoZySu>. Acesso em: 6 set. 2017.

CORTE INTERAMERICANA DE DIREITOS HUMANOS (CIDH). Caso Las Palmeras Vs. Colômbia. Supervisão de Cumprimento de Sentença. Resolução da Corte Interamericana de Direitos Humanos de 4 de agosto de 2008a. Disponível em: <https://goo.gl/CQa6r8>. Acesso em: 6 set. 2017.

CORTE INTERAMERICANA DE DIREITOS HUMANOS (CIDH). Caso Las Palmeras Vs. Colômbia. Supervisão de Cumprimento de Sentença. Resolução da Presidenta da Corte Interamericana de Direitos Humanos de 7 de dezembro de 2009a. Disponível em: $<$ https://goo.gl/nBbucH>. Acesso em: 6 set. 2017.

CORTE INTERAMERICANA DE DIREITOS HUMANOS (CIDH). Caso Las Palmeras Vs. Colômbia. Supervisão de Cumprimento de Sentença. Resolução da Corte Interamericana de Direitos Humanos de 3 de fevereiro de 2010. Disponível em: <https://goo.gl/pfZhgN>. Acesso em: 6 set. 2017.

CORTE INTERAMERICANA DE DIREITOS HUMANOS (CIDH). Caso Massacre de Mapiripán vs. Colômbia. Sentença de 15 de setembro de 2005. Disponível em: <https://goo.gl/WuB6yr>. Acesso em: 6 set. 2017.

CORTE INTERAMERICANA DE DIREITOS HUMANOS (CIDH). Caso Massacre de Mapiripán vs. Colômbia. Supervisão de Cumprimento de Sentença. Resolução da Corte Interamericana de Direitos Humanos de 26 de novembro de 2008c. Disponível em: <https://goo.gl/xQe52X>. Acesso em: 6 set. 2017.

CORTE INTERAMERICANA DE DIREITOS HUMANOS (CIDH). Caso Massacre de Mapiripán vs. Colômbia. Supervisão de Cumprimento de Sentença. Resolução do Presidente da Corte Interamericana de Direitos Humanos de 8 de fevereiro de 2012b. Disponível em: $<$ https://goo.gl/xUGe5z>. Acesso em: 6 set. 2017.

CORTE INTERAMERICANA DE DIREITOS HUMANOS (CIDH). Caso Massacre de Mapiripán vs. Colômbia. Supervisão de Cumprimento de Sentença. Resolução da Corte Interamericana de Direitos Humanos de 23 de novembro de 2012c. Disponível em: <https://goo.gl/eQoeAD>. Acesso em: 6 set. 2017. 
CORTE INTERAMERICANA DE DIREITOS HUMANOS (CIDH). Caso Massacre de Pueblo

Bello Vs. Colômbia. Sentença de 31 de janeiro de 2006b. Disponível em: <https://goo.gl/LW1ShZ>. Acesso em: 6 set. 2017.

CORTE INTERAMERICANA DE DIREITOS HUMANOS (CIDH). Caso Massacre de Pueblo Bello Vs. Colômbia. Solicitação de Interpretação de Sentença, de 25 de novembro de 2006c. Disponível em: <https://goo.gl/dQsz5N>. Acesso em: 6 set. 2017.

CORTE INTERAMERICANA DE DIREITOS HUMANOS (CIDH). Caso Massacre de Pueblo Bello Vs. Colômbia. Supervisão de Cumprimento de Sentença. Resolução da Corte Interamericana de Direitos Humanos de 26 de novembro de 2008d. Disponível em: <https://goo.gl/bicDMB $>$. Acesso em: 6 set. 2017.

CORTE INTERAMERICANA DE DIREITOS HUMANOS (CIDH). Caso Massacre de Pueblo Bello Vs. Colômbia. Supervisão de Cumprimento de Sentença. Resolução da Corte Interamericana de Direitos Humanos de 9 de julho de 2009c. Disponível em: <https://goo.gl/WQuSCt>. Acesso em: 6 set. 2017.

CORTE INTERAMERICANA DE DIREITOS HUMANOS (CIDH). Caso Massacre de Pueblo Bello Vs. Colômbia. Supervisão de Cumprimento de Sentença. Resolução da Corte Interamericana de Direitos Humanos de 8 de fevereiro de 2012d. Disponível em: <https://goo.gl/Rnw668>. Acesso em: 6 set. 2017.

CORTE INTERAMERICANA DE DIREITOS HUMANOS (CIDH). Caso Massacre de Santo Domingo Vs. Colômbia. Sentença de 30 de novembro de 2012e. Disponível em: <https://goo.gl/2kaHpu>. Acesso em: 6 set. 2017.

CORTE INTERAMERICANA DE DIREITOS HUMANOS (CIDH). Caso Massacre de Santo Domingo Vs. Colômbia. Solicitação de Interpretação de Sentença, de 19 de agosto de 2013a. Disponível em: <https://goo.gl/7JAUU1>. Acesso em: 6 set. 2017.

DONNELLY, Jack. Universal Human Rights: in theory and in practice. $2^{\text {nd }}$ edition. Ithaca: Cornell University Press, 2003.

FLORES, Joaquín Herrera. A (re)invenção dos direitos humanos. Florianópolis: Boiteux, 2009.

GREER, Steven. The Margin Of Appreciation: Interpretation And Discretion Under The European Convention On Human Rights. Council of Europe, 2000.

OLIVEIRA, Márcio Luís de. O sistema interamericano de proteção dos direitos humanos: interface com o direito constitucional contemporâneo. Belo Horizonte: Del Rey, 2007.

PASQUALUCCI, Jo M. The Practice and Procedure of the Inter-American Court of Human Rights. Nova Iorque: University of South Dakota Press, 2014.

PIOVESAN, Flávia. Direitos Humanos e Justiça Internacional. São Paulo: Saraiva, 2011.

PIOVESAN, Flávia. Direitos humanos e diálogo entre jurisdições. Revista Brasileira de Direito Constitucional - RBDC, São Paulo, n.19, p. 72, jan./jun. 2012. 
PIOVESAN, Flávia. Direitos sociais, econômicos e culturais e direitos civis e políticos. Sur Revista Internacional de Direitos Humanos, São Paulo, 2004.

TRINDADE, Antônio Augusto Cançado. Dilemas e desafios da proteção internacional dos direitos humanos no limiar do século XXI. Revista Brasileira de Política Internacional, Brasília, p. 167177, jan./jun. 1997. Disponível em: <https://goo.gl/mwHGDD>. Acesso em: 6 dez. 2012.

TRINDADE, Antônio Augusto Cançado; ROBLES, Manuel E. Ventura. El Futuro de la Corte Interamericana de Derechos humanos. San José, Costa Rica: Corte Interamericana de Direitos Humanos e UNHCR, 2003.

TRINDADE, Antônio Augusto Cançado. The Inter-American System of Protection of Human Rights (1948-2005): evolution, present state and perspectives. In: Apostila do Curso Fundamental [em inglês] do Instituto Internacional dos Direitos do Homem (IIDH), sessão de 4-29 de julho de 2005.

WILT, Harmem van der; KRSTICEVIC, Viviana. The OAS System and Human Rights. In: HANSKI, Raija; SUKSI, Markku. An Introduction to the International Protection of Human Rights. 2nd edition. Turku: Institute for Human Rights Abo Akademi University, 2004. p. 371.

Ananda Hadah Rodrigues Puchta Bacharel em Direito pela Universidade Federal do Paraná (2013) e especialista em Direito Constitucional pela Academia Brasileira de Direito Constitucional (2015). Pesquisadora em Direito Constitucional, Direitos Fundamentais e Direito Internacional dos Direitos Humanos na Universidade Federal do Paraná. Integra o Núcleo de Pesquisa Constitucionalismo e Democracia e o Núcleo de Estudos de Sistemas de Direitos Humanos da UFPR. Advogada. Membro da Comissão de Diversidade Sexual e de Gênero da OAB/PR. Coordenadora Jurídica de Organismos Internacionais do Grupo Dignidade e da Aliança Nacional LGBTI. E-mail: ananda.hadah.rp@gmail.com

Melina Girardi Fachin Doutora em Direito pela PUC-SP. Professora Adjunta no Programa de Pós-Graduação em Direito da Universidade Federal do Paraná. E-mail: melinafachin@gmail.com

Bacharel em Direito pela Universidade Federal do Paraná. E-mail: giulia.bolzani@gmail.com 